\title{
Cognitive disorders in 6-hydroxydopamine-induced rat model of Parkinson's disease
}

\author{
Lucian Hritcu*, Alin Ciobica and Vlad Artenie
}

Address: Department of Molecular and Experimental Biology, Alexandru Ioan Cuza University, Iasi, Romania

* Corresponding author

from International Society on Brain and Behaviour: 3rd International Congress on Brain and Behaviour

Thessaloniki, Greece. 28 November - 2 December 2007

Published: 17 April 2008

Annals of General Psychiatry 2008, 7(SuppI I):S248 doi:I0.1 I86/I744-859X-7-SI-S248

This abstract is available from: http://www.annals-general-psychiatry.com/content/7/SI/S248

(C) 2008 Hritcu et al.; licensee BioMed Central Ltd.

\section{Background}

Parkinson's disease is a human neurodegenerative disorder which is mainly characterized by a massive and progressive degeneration of the dopaminergic neurons in the substantia nigra (SN). The most widely used animal models of Parkinson's disease involve intracranial infusion of the neurotoxin 6-hydroxydopamine (6-OHDA) directly into the ascending dopaminergic forebrain bundle, thereby, inducing severe dopaminergic neuronal degeneration associated with profound deficits in feeding, drinking, sensorimotor and learning functions [1-4]. The aim of the present work was to study the effects of right-unilateral 6-OHDA lesions of the ventral tegmental area (VTA) or substantia nigra pars reticulata (SNr) on learning and memory processes evidenced by means of Y-maze task and shuttle-box task, respectively. We also examined the effect of nicotine treatment on the 6-OHDA lesioned rats. Our data suggest that a correlation exist between VTA, $\mathrm{SNr}$ and nAchRS and expression of cognitive capacities.

\section{Materials and methods}

Male Wistar rats were subjected to right-unilateral 6hydroxydopamine (6-OHDA) $(8 \mu \mathrm{g} / 4 \mu \mathrm{l})$ lesions of the ventral tegmental area (VTA) or substantia nigra pars reticulata (SNr), or were sham lesioned, and nicotine treatment and their ability to acquire the operant task was studied by means of Y-maze task and shuttle-box task, respectively. For the lesioning of the $\mathrm{SN}$ the following coordinates were used: $5.5 \mathrm{~mm}$.
Posterior to bregma; $2.0 \mathrm{~mm}$ lateral to the midline; 7.4 $\mathrm{mm}$ ventral to the surface of the cortex. For lesioning the VTA, the following coordinates were used: $5.6 \mathrm{~mm}$.

Posterior to bregma; $0.5 \mathrm{~mm}$ lateral to the midline; 7.6 $\mathrm{mm}$ ventral to the surface of the cortex. The sham-operated rats were injected with saline. Learning and memory tests were began 2 weeks after the operation.

\section{Results}

Lesions of both VTA and SNr resulted in an impairment of both conditioned avoidance response and crossing latency tested by means of shuttle-box task, suggesting significant effects of long-term memory. 6-OHDA significantly decreased spontaneous alternation in Y-maze task, suggesting effects on spatial memory, especially on shortterm memory. A low dose of nicotine $(0.3 \mathrm{mg} / \mathrm{kg}$ b.w., i.p.), a specific nicotinic acetylcholine receptors (nAchRS), administrated 4 consecutively days attenuated the impairment of learning and memory processes in 6-OHDA lesioned rats.

\section{Conclusions}

These data suggest that VTA, SN and nAchRS have a facilitator role in learning and memory processes. Therefore, the integrity of these nervous areas may be necessary for processing and storage of information.

\section{Acknowledgements}

This research was supported by the National Council of Scientific Research and University Education (CNCSIS), Grant A, no. 639, Romania. 


\section{References}

I. Kitayama T, Onitsuka Y, Song L, Morioka N, Morita K, Dohi T: Assessing an eating disorder induced by 6-OHDA and the possibility of nerve regeneration therapy by transplantation of neural progenitor cells in rats. Nihon Shinkei Seishin Yakurigaku Zasshi 2007, 27(3):109-16.

2. Fitzsimmons DF, Moloney TC, Dowd E: Further validation of the corridor task for assessing deficit and recovery in the hemiParkinsonian rat: restoration of bilateral food retrieval by dopamine receptor agonism. Behav Brain Res 2006, I 5: 169(2):352-355

3. Shimura T, Kamada Y, Yamamoto T: Ventral tegmental lesions reduce overconsumption of normally preferred taste fluid in rats. Behav Brain Res 2002, I34(I-2): 123-130.

4. Hefco V, Yamada K, Hefco A, Hritcu L, Tiron A, Nabeshima T: Role of the mesotelencephalic dopamine system in learning and memory processes in the rat. Eur J Pharmacol 2003, 15;475(I3):55-60.

Publish with Bio Med Central and every scientist can read your work free of charge

"BioMed Central will be the most significant development for disseminating the results of biomedical research in our lifetime. "

Sir Paul Nurse, Cancer Research UK

Your research papers will be:

- available free of charge to the entire biomedical community

- peer reviewed and published immediately upon acceptance

- cited in PubMed and archived on PubMed Central

- yours - you keep the copyright

Submit your manuscript here:

http://www.biomedcentral.com/info/publishing_adv.asp 